University of California, Hastings College of the Law UC Hastings Scholarship Repository

Faculty Scholarship

2007

\title{
Conscientious Objection as a Basis for Refugee Status Protection for the Fundamental Right of Freedom of Thought, Conscience, and Religion
}

Karen Musalo

UC Hastings College of the Law, musalok@uchastings.edu

Follow this and additional works at: http://repository.uchastings.edu/faculty_scholarship

\section{Recommended Citation}

Karen Musalo, Conscientious Objection as a Basis for Refugee Status Protection for the Fundamental Right of Freedom of Thought, Conscience, and Religion, 26(2) Refugee Survey Quarterly 69 (2007).

Available at: http://repository.uchastings.edu/faculty_scholarship/1152 


\title{
CONSCIENTIOUS OBJECTION AS A BASIS FOR REFUGEE STATUS: PROTECTION FOR THE FUNDAMENTAL RIGHT OF FREEDOM OF THOUGHT, CONSCIENCE AND RELIGION
}

\author{
Karen Musalo \\ Professor, University of California, Hastings College of the Law, United States
}

It is beyond dispute that sovereign nations have the right to raise and maintain armies. This right may come in conflict with the right to conscientious objection, which has increasingly been recognized as a legitimate exercise of freedom of thought, conscience and religion. Individuals who face mandatory military service in contravention of their deep moral convictions, may flee their home countries, and seek refugee status abroad as a solution. Their recognition as refugees depends on a broad constellation of factors, including the particular basis for their refusal to serve, the nature of the military conflict itself, and the degree to which the State in which they seek asylum follows the guidance of the United Nations High Commissioner for Refugees (UNHCR) on the issue of draft evasion and desertion as a basis for protection.

This article will examine the trends regarding the protection of the individual whose claim to refugee status is premised upon a conscientious objection to military service. It will begin by examining the internationally recognized right to freedom of thought, conscience and religion, and discuss its relationship to conscientious objection. It will then examine the position and underlying rationale of the United Nations High Commissioner for Refugees on the issue. It will look at the trends in a number of common law countries, and evaluate the degree to which UNHCR guidance and other relevant human rights norms are respected. It will conclude by recommending a more robust protection of individuals of conscience who do not want to participate in the military.

Keywords: Freedom of religion, freedom of thought, conscience and religion, conscientious objection and refugee status.

\section{CONSCIENTIOUS OBJECTION AND ITS RELATIONSHIP TO FREEDOM OF THOUGHT, CONSCIENCE AND RELIGION}

A conscientious objection to military service is one that is premised on deeplyheld beliefs. It can manifest as pacifism - an objection to fighting in all wars - or it can be a selective objection to a particular conflict. The Office of the High Commissioner for Human Rights recently characterized conscientious objection as an objection to service based on "principles and reasons of conscience, including profound convictions, arising from religious, moral, ethical, humanitarian or other motives." 
Although the right to conscientious objection is not expressly recognized by relevant international instruments, many scholars have remarked upon the "recent and well-established trend in the international community" ${ }^{2}$ to interpret the right to freedom of thought, conscience and religion as encompassing the right to conscientious objection.

The recognition of freedom of religion or belief as a fundamental human right is well-established in numerous international ${ }^{3}$ and regional instruments. ${ }^{4}$ Although the right to freedom of thought, conscience and religion had limited recognition in international law as early as the sixteenth century, ${ }^{5}$ it was with the establishment of the United Nations that the right has its origins as an international norm. Art. 18 of the Universal Declaration of Human Rights (UDHR) specifically ${ }^{6}$ addresses the right as follows:

Everyone has the right to freedom of thought, conscience and religion; this right includes freedom to change his religion or belief, and freedom, either alone or in community with others and in public or private, to manifest his religion or belief in teaching, practice, worship and observance. ${ }^{7}$

The principles articulated in the UDHR were incorporated into Art. 18 of the International Covenant on Civil and Political Rights (ICCPR), and in 1981 the U.N. General Assembly adopted by unanimous vote the Declaration on the Elimination of All Forms of Intolerance and of Discrimination Based on Religion or Belief. ${ }^{8}$

Whether conscientious objection is itself an internationally recognized right - or simply an emerging human rights norm - has been a matter of some controversy. In 1985, the U.N. Human Rights Committee, which monitors the ICCPR's implementation, stated that the Covenant did not provide for the right to conscientious objection. ' However, in 1993 it reversed its position, stating that although the "Covenant does not explicitly refer to a right to conscientious objection, ...the committee believes that such a right can be derived from article 18 , inasmuch as the obligation to use lethal force may seriously conflict with the freedom of conscience and the right to manifest one's religion or belief." 10

Resolutions issued by the U.N. Human Rights Commission have been in accord with this evolving recognition. In 1987, the Commission appealed to States to "recognize that conscientious objection to military service should be considered a legitimate exercise of the right to freedom of thought, conscience and religion. ${ }^{11}$ In 1995, the Commission once again noted "the right of everyone to have conscientious objections to military service as a legitimate exercise of the right to freedom of thought, conscience and religion[.]"12 It reiterated this position once more in $1998 .{ }^{13}$

\section{CONSCIENTIOUS OBJECTION AS A BASIS FOR REFUGEE STATUS}

The United Nations High Commissioner for Refugee Status has addressed conscientious objection as a basis for refugee status in its Handbook, ${ }^{14}$ as well as in it recently released Religion Guidelines. ${ }^{15}$ In a section of the Handbook entitled 
"Special Cases", UNHCR sets forth a framework for determining when refugee status may be premised upon draft evasion or desertion.

The Handbook begins its analysis by stating the widely accepted rule that punishment for evasion or desertion is not normally considered to be persecution, and that aversion to military service, or fear of combat are not legitimate reasons for refusal to serve. ${ }^{16}$ However, the Handbook carves out two exceptions to the general rule that it is not persecution to require military service; relevant for our purposes is the exception which arises when the "performance of military service would have required ...participation in military action contrary to ...genuine political, religious, or moral convictions, or to valid reasons of conscience." ${ }^{17}$

The individual who objects for religious, moral or valid reasons of conscience must demonstrate the sincerity of his beliefs, the fact that military service is obligatory, and that the State provides no accommodation for these beliefs. ${ }^{18} \mathrm{~A}$ failure of accommodation could be based upon a showing that State law does not provide an exemption for conscientious objectors, and that young men only have the option of serving or being punished for refusal to serve. The individual whose objections to military service are based on political convictions; i.e., the person who is "in disagreement with his government regarding the political justification for a particular military action," must meet one additional criteria; he must establish that the type of military action to which he objects "is condemned by the international community as contrary to basic rules of human conduct." ${ }^{19}$

The recommendation of refugee status for those who refuse service for reasons of conscience was reaffirmed by UNHCR in its Religion Guidelines, which state:

Where military service is compulsory, refugee status may be established if the refusal to serve is based on genuine political, religious, or moral convictions, or valid reasons of conscience.... Prosecution and punishment pursuant to a law of general application is not generally considered to constitute persecution... In conscientious objector cases, a law purporting to be of general application may, depending on the circumstances, nonetheless be persecutory where, for instance....the military service cannot reasonably be expected to be performed by the individual because of his or her genuine beliefs or religious convictions. ${ }^{20}$

Furthermore, this approach has been explicitly adopted by the U.N. High Commissioner for Human Rights. Included in its list of "best practices" in relation to implementation of the right to conscientious objection, is the policy that "asylum should be granted to those conscientious objectors compelled to leave their country of origin because they fear persecution owing to their refusal to perform military service." 21

\section{A SURVEY OF STATE PRACTICES ON REFUGEE STATUS FOR CONSCIENTIOUS OBJECTORS}

Notwithstanding the strong recommendation of UNHCR and the UNHCHR, States have erected many jurisprudential barriers to deny refugee protection to conscientious objectors. As will be discussed below, the U.S. has often employed 
an overly formalistic nexus analysis to deny protection to religiously-motivated conscientious objectors. In cases involving American conscientious objectors to the U.S. war in Iraq, Canada has adopted a troubling approach to determining whether the military service "is condemned by the international community as contrary to basic rules of human conduct" as required by the U.N. Handbook in cases involving objections based on political convictions. There have been some positive developments in jurisprudence in the U.K., but resistance to recognizing the right to conscientious objection as an internationally protected right has resulted in denial of protection. Disappointingly, the recent Qualification Directive $^{22}$ which sets forth standards for refugee norms within the European Union, has taken an overly narrow approach which is inconsistent with more positive developments within the E.U. on the issue of conscientious objection, and which will serve to thwart expanded protections. In contrast, New Zealand has adopted an approach explicitly anchored in international human rights norms.

\section{The United States}

\section{Religiously-Motivated Claims}

In 1992 the U.S. Supreme Court ruled that the refugee definition's requirement that persecution be "on account of" one of the five Convention grounds required proof of the persecutor's motivation. This interpretive approach, which has been broadly criticized, ${ }^{23}$ has adversely impacted claims for refugee status based on conscientious objection - especially religiously-motivated conscientious objection - because courts have consistently ruled that the government's intent was to raise an army, not to persecute the applicant for his or her religion or belief. The landmark case on this issue is Cañas-Segovia v. INS, ${ }^{24}$ ruling that it is not religious persecution to punish Jehovah's Witnesses ${ }^{25}$ for refusing to perform military service. ${ }^{26}$

However, even with the obstacle to religiously-motivated conscientious objection cases posed by the intent requirement, there have been some U.S. decisions recognizing the viability of such claims. These cases generally involve an element of disproportionate punishment and/or pervasive discrimination against the religious group in question, and it is these factors that result in a grant of protection. ${ }^{27}$

\section{Political Conviction Claims}

As noted in the discussion of the Handbook's guidance, objectors whose refusal to serve is based on political disagreement with the military action must make the additional showing that the military action be "condemned by the international community as contrary to basic rules of human conduct[.]" Some cases in the U.S. have not fared well because of the standard employed to determine whether or not the military action meets this standard. Several cases have interpreted the U.N. Handbook as requiring an actual U.N. resolution condemning the military action. $^{28}$ 


\section{Canada}

Canada has generally taken a more humanitarian-oriented approach on conscientious objection cases. It has not followed the "intent" requirement of the United States, but has adopted a nexus analysis which looks to either the intent or the effects of the law requiring military service. The principal case setting forth this approach is Zolfagharkhani v. Canada ${ }^{29}$ involving an Iranian who did not want to serve in the military of his country after he learned that the government intended to use chemical warfare against the Kurds..$^{30}$ The Court ruled that "the ... definition of Convention refugee makes the intent (or any principal effect) of an ordinary law of general application ... relevant to the existence of persecution." ${ }^{31}$ Canadian tribunals have consistently applied an interpretation contemplating protection in cases involving objections to military service based on religion or belief. ${ }^{32}$

However, recent claims by American servicemen, Jeremy Hinzman and Brandon David Hughey, who have refused service in Iraq because of their genuine political convictions have not resulted in protection. The cases, Hinzman $v$. Canada ${ }^{33}$, and Hughey v. Canada ${ }^{34}$ examined the criteria set forth in Handbook para. 171; namely that "the type of military action, with which an individual does not with to be associated, is condemned by the international community as contrary to basic rules of human conduct[.]" The applicants raised two broad bases for their claims that they met this criteria, arguing that: (1) the U.S. invasion of Iraq constituted an illegal war, and on that fact alone they met the standard, and (2) violations of rules of war were sufficiently pervasive to establish a sufficient likelihood of being directly implicated in activities contrary to basic rules of human conduct.

Among the arguments made to support the assertion that the war itself was illegal, one of the claimants submitted affidavits from international law experts, who pointed to the lack of a U.N. Security Council approval for the invasion, and noted that the U.N. Charter only permits the use of force by a country in cases of self-defense, or with Security Council approval. On the issue of the pervasiveness of humanitarian law violations, the claimants pointed to reports by the International Committee of the Red Cross (IRRC), Human Rights Watch, and Amnesty International. Mr. Hughey also submitted evidence about the treatment of prisoners at Guantánamo, Cuba, the practice of torture at Abu Ghraib prison in Iraq, and legal opinions by the U.S. Department of Justice which suggested that the Convention against Torture and Other Cruel, Inhuman and Degrading Treatment, might not apply to "enemy combatants" held by the United States.

The court denied Hinzman's claim rejecting both arguments. It ruled that the illegality of the war could not be called upon as a basis for a "mere foot soldier" 35 and that there was no evidence to show that the "breaches of international humanitarian law that have been committed by American soldiers in Iraq ... rise to the level of being either systematic or condoned by the state." ${ }^{36}$ It relied upon this latter finding to rule that there was insufficient evidence to establish that the military action in which he could be involved would be "condemned by the international community as contrary to basic rules of human conduct." 
The court in Hughey also denied the applicant's claim, but it did leave the door somewhat open. On the issue of the illegality of a war being relevant in cases involving foot soldiers, the court cited to its earlier decision, Al-Maisri v. Canada ${ }^{37}$ in ruling that the issue was "not entirely free from doubt" 38 and it certified the question. However, it ruled in concert with the Hinzman court on the question of the likelihood of involvement with acts contrary to basic rules of conduct, observing that he had not established that the U.S. engaged in "systematic violations of humanitarian law." 39

A broader human rights perspective on these cases is provided by a 2005 Amnesty International briefing on the case of Jeremy Hinzman. After stating its position that the right to refuse military service for reasons of conscience is "inherent in the notion of freedom of thought, conscience and religion," and expressing its assessment of Mr. Hinzman as a genuine conscientious objector, AI concludes that if he were to be forcibly returned to the U.S. and imprisoned, it would "adopt him as a prisoner of conscience." ${ }^{40}$

\section{United Kingdom}

In Sepet v. Secretary of State for the Home Department ${ }^{41}$ the House of Lords considered a case involving two Kurdish asylum seekers who objected to military service in Turkey where they believed they would be compelled to fight against fellow Kurds and engage in acts contrary to international norms. The claim was analyzed as one premised on "political" objections under U.N. Handbook para. 171, and was denied on the basis of a failure to show international condemnation of Turkish military action against the Kurds.

In a subsequent case, Krotov v. Secretary of State for the Home Department ${ }^{42}$ the federal court moved jurisprudence in a positive direction by shifting the emphasis away from the requirement of an international condemnation to that of an evaluation of the military action within a human rights framework. Krotov involved the claim for refugee status of a citizen of the Russian Federation who deserted from military service in the Chechen war. In rejecting the requirement of international condemnation, the court noted that to "hinge the test on international condemnation would mean having to assess military service cases ... on the basis of the vagaries of international politics, apt to vary depending on shifting alliances and whether other countries surveying the conflict take a particular view." 43

The court observed that a "test based directly in international law" would be more consistent with the "overall framework" of the Refugee Convention, and noted that to do otherwise would be to "subvert...underlying principles of interpretation set out by the House of Lords in Horvath.... which seek to base interpretation of the Refugee Convention on fundamental norms and values drawn from international law sources, in particular international human rights law...."44

After having ruled that the proper test is not whether the international community has officially condemned the action, but whether it contravenes accepted legal standards, the court identified "core humanitarian norms" which govern such determination, including Common art. 3 to the Geneva Convention of 1949, and its Additional Protocol II. If acts prohibited by these instruments are 
"committed on a systemic basis as an aspect of deliberate policy, or as a result of official indifference to the widespread actions of a brutal military" the individual who has a well-founded fear of punishment for refusal to participate will come within the refugee definition.

\section{New Zealand}

In the past, New Zealand took an approach similar to that of the U.S. It cited the fact that military service is imposed by way of a law of universal application to rule that neither the service itself nor punishment for refusal was linked to a Convention reason..$^{45}$ On this basis it denied claims of a Russian citizen with religious and moral objections to serving in Chechnya ${ }^{46}$ a national of Ukraine and the Russian Federation with religious objections to serving in Chechyna; ${ }^{47}$ and two separate cases of Jehovah's Witnesses from South Korea. ${ }^{48}$

Subsequently the Refugee Status Appeals Authority (RSAA) modified its position, concluding that an intent to persecute was not required; what was required was only a showing that the "Convention-protected ground was a 'contributing cause' to the risk of being persecuted..$^{49}$ In addition to the shift away from requirement of proof of intent, the RSAA "reaffirmed its preference for determining refugee status issues via what has become known as the "human rights approach[.]"'50

The RSAA employed this approach to rule in favor of a Kurdish conscientious objector from Turkey. In deciding the case, the RSAA referred to the "proposition that no one can be compelled to undertake military service where a real chance exists that this will require the refugee claimant to commit human rights abuses." ${ }^{51}$ It reached the conclusion that such a risk existed in light of "the history of the conflict, attendant breaches of the laws of war on a widespread scale in the past and a continuing climate of impunity for those who commit the breaches[.]" ${ }^{2}$ The likelihood of being compelled to commit humanitarian law violations transformed his potential imprisonment for resisting service into persecution for a Convention reason.

\section{The European Union}

One scholar, Cecilia Bailliet, has noted that developments regarding conscientious objection within the European Union display a type of "schizophrenia." 33 Bailliet refers to encouragement of members by the Council of Europe Parliamentary Assembly "to adopt national legislation recognizing the right of conscientious objection as derived from fundamental rights of the individual[.]" 54 However, at the same time, the Council of the European Union adopted a Qualification Directive which provides for refugee status for draft resisters or evaders which is far more limited than that recommended by the UNHCR.

The Qualification Directive, at Art. 9(1) defines persecution; prosecution or punishment for refusal to perform military service only constitutes persecution "where performing military service would include crimes or acts falling under the exclusion clauses[.]" ${ }^{55}$ Whereas the UNHCR recommends refugee status whenever the military service is contrary to "genuine political, religious or moral 
convictions, or to valid reasons of conscience" 56 the Directive limits it to those extreme circumstances where the individual would be engaged in crimes against peace, war crimes, crimes against humanity, serious non-political crimes, or acts contrary to the purposes and principles of the United Nations.

This position has been criticized by UNHCR as well as the European Council on Refugees and Exiles (ECRE). In its criticism UNHCR reiterated its long-held position that punishment for refusal to perform military service "may also be considered to be persecutory, if the reasons for refusal are based on deeply held moral, religious, or political convictions. ${ }^{57}$ ECRE lamented that the Qualification Directive limited itself to "scenarios where individuals would be required to commit war crimes or other serious crimes as part of their military service" and considered it "unfortunate that the original wording of the Commission proposal was not retained which allowed for the reasons for the refusal to perform military service to be based on deeply held moral, religious, or political convictions" which would be consistent with the "UNHCR Handbook and evolving human rights laws." 58

\section{CONCLUSION}

One of the most fundamental moral choices an individual can make is whether to kill another human being. Service in the military confronts the individual with this possibility, and raises profound questions of conscience. It is encouraging that there is a greater recognition that conscientious objection is a legitimate exercise of the right to freedom of thought, conscience and religion. However, the refugee practice of many countries continue to interpret the law in a way which denies protection to genuine conscientious objectors. State practice should better reflect the guidance and recommendations of UNHCR, and avoid overly formalistic analyses which result in the limiting protection to young men who do not wish to bear arms.

\section{Notes}

U.N. Econ. \& Soc. Council, Report of the Office of the High Commissioner for Human Rights, Civil and Political Rights, Including the Question of Conscientious Objection to Military Service, U.N. Doc. E/ CN.4/2004/55 (Feb.16 2004) para. 38(c).

2 Emily N. Marcus, "Conscientious Objection as an Emerging Human Right," 38 Va.J.Int'l L. 507, 509 (Spring 1998)

3 See, for example, Universal Declaration of Human Rights, UNGA res. 217A(III), 10 Dec. 1948, art. 18 [hereinafter "Universal Declaration" or "UDHR"]; International Covenant on Civil and Political Rights, UNGA res. 2200A(XXI), 23 Mar. 1976, art. 18 [hereinafter 'ICCPR' or 'CCPR']; Declaration on the Elimination of All Forms of Intolerance and Discrimination Based on Religion or Belief, UNGA res. 36/55, 25 Nov. 1981, art. 1 [hereinafter 'Declaration'].

4 See, for example, art. 9 of the European Convention for the Protection of Human Rights and Fundamental Freedoms, 213 U.N.T.S. 222 (entered into force Sept. 3, 1953) [hereinafter ECHR]; art. 12 of the American Convention on Human Rights, O.A.S. Treaty Series No. 36, 1144 U.N.T.S. 123 (entered into force July 18, 1978); art. 8 of the African Charter on Human and Peoples' Rights, adopted June 27, 1981, O.A.U. Doc. CAB/LEG/67/3 Rev.5, 21 I.L.M. 58 (1982)(entered into force Oct. 21, 1986); Principle VII of the Final Act of the Conference on Security and Cooperation in Europe (Helsinki Accords)(adopted Aug. 1, 1975).

5 Arcot Krishnaswami, Special Rapporteur of the Sub-Commission on Prevention of Discrimination and Protection of Minorities, "Study of Discrimination in the Matter of Religious Rights and Practices," UN Doc. E/CN.4/Sub.2/200/Rev. 1 (1960), see generally introduction [hereinafter 'Krishnaswami Report']. See 
also Karen Musalo, "Irreconcilable Differences? Divorcing Refugee Protections from Human Rights Norms" (1994) 15 Mich. J. Int'l Law 1179 (detailing existence of unilateral and multilateral treaties for the limited protection of the rights of religious minorities).

6 Both the Charter of the United Nations, 26 June 1945, and the UDHR art. 2 contain more general provisions regarding religion. Art. 1 of the U.N. Charter affirms that a fundamental purpose of the United Nations is "promoting and encouraging respect for human rights and for fundamental freedoms for all without distinction as to race, sex, language, or religion", while art. 2 of the UDHR provides that: "Everyone is entitled to all the rights and freedoms set forth in this Declaration, without distinction of any kind, such as race, colour, sex, language, religion, political or other opinion, national or social origin, property, birth or other status."

UDHR, n. 3 above, art. 18.

Declaration, n. 3 above, item 75.

$9 \quad$ LTK v. Finland (1985) 94 ILR 396.

10 Office of the High Commissioner for Human Rights, "General Comment 22: The right to freedom of thought, conscience and religion (Art. 18)," CCPR/C/21/Rev.1/Add.4, General Comment No. 22 (July 30, 1993), available at http://www.unhchr.ch/tbs/doc.nsf/0/9a30112c27d1167cc12563ed004d8f15?OpenDocument.

11 Report of the Office of the High Commissioner for Human Rights, Civil and Political Rights, Including the Question of Conscientious Objection to Military Service, supra, note 1, at para. 16.

12 Id., at para. 17.

13 Id., at para. 18.

14 Office of the United Nations High Commissioner for Refugees, Handbook on Procedures and Criteria for Determining Refugee Status (1992).

15 Guidelines on International Protection, Religion-Based Refugee Claims under Article 1A(2) of the 1951 Convention and/or the 1967 Protocol relating to the Status of Refugees, HCR/GIP/04/06 (April 28, 2004), available at http://www.unhcr.org/publ/PUBL/40d8427a4.pdf.

16 Handbook, supra at n. 14, para. 167-168.

17 Handbook, supra at n. 14, para. 170.

18 Handbook, supra at n. 14, para. 170, 172-174.

19 Handbook, supra at n. 14, para. 171.

20 Religion Guidelines, supra, note 15, para 26.

21 Report of the Office of the High Commissioner for Human Rights, Civil and Political Rights, Including the Question of Conscientious Objection to Military Service, supra, note 1, at para. 38(h).

22 Council Directive 2004/83/EC on minimum standards for the qualification and status of third country nationals or stateless persons as refugees or as persons who otherwise need international protection and the content of the protection granted, 2004 OJ (L 304), available at http://register.consilium.eu.int/pdf/en/04/ st08/st08043.en04.pdf.

23 See Karen Musalo, "Irreconcilable Difference? Divorcing Refugee Protections from Human Rights Norms," 15 Michigan Journal Law 1179 (1994) for a general critique of the requirement of proof of motivation.

$24 \quad$ INS v. Cañas-Segovia, 970 F.2d 599 (9th Cir. 1992)

25 The official position of the Jehovah's Witnesses regarding military service is as follows:

"Jehovah's Witnesses are conscientiously opposed to war and to their participation in such in any form whatsoever. For this reason they inform officials of the government that they conscientiously object to serving in the military, in any substitute service therefor or in any civilian capacity which fosters or supports the military...." The National Interreligious Service Board for Conscientious Objectors, Words of Conscience, Religious Statements on Conscientious Objection 115 (10 $0^{\text {th }}$ Ed. 1983), quoted in Karen Musalo, "Swords into Ploughshares: Why The United States Should Provide Refuge to Young Men who Refuse to Bear Arms for Reasons of Conscience," (1989) 26 San Diego L. Rev. 849, 866 n. 88.

26 This ruling was contrary to the position urged by the UNHCR in a brief amicus curiae in Cañas, authored by Guy Goodwin-Gill, Susan Timberlake and Ralph Steinhardt, reproduced in 2 Int. J. Ref. Law 390 (1990). There are two Ninth Circuit decisions; Cañas-Segovia v. INS, 902 F.2d 717 (9 $9^{\text {th }}$ Cir. 1990)(Cañas I) and Cañas-Segovia v. INS, 970 F.2d 599 (9 $9^{\text {th }}$ Cir. 1992)(Cañas II). In Cañas I, decided before the U.S. Supreme Court imposed an intent requirement, the Ninth Circuit found that to punish a conscientious objector for adherence to his religious beliefs had the effect of persecuting him for his religion, and therefore is persecution "on account of religion." After the Supreme Court adopted an intent requirement, it vacated Cañas I, and remanded it to the Ninth Circuit. (112 S.Ct. 1152) In light of the intent requirement, the Ninth Circuit Court of Appeals ruled that it could no longer find persecution on account of religion.

27 Two cases which illustrate this are Ilchuk v. Atty. Gen. of the U.S., 434 F.3d 618 (3d Cir. 2006) and Ghebremedhin v. Ashcroft, 385 F. 3d 1116 ( $7^{\text {th }}$ Cir. 2004), amended 392 F.3d 241 ( $7^{\text {th }}$ Cir. 2004). In Ilchuk the court noted that the right to refuse service was only guaranteed to religions with legal status in the Ukraine; it was this discriminatory aspect that was dispositive. In Ghebremedhin, a case involving a Jehovah's Witness in Ethiopia, the court found a pervasive "history of persecution" against adherents of the religion, and noted the disproportionate punishment to which Jehovah's Witness were subject.

28 M.A. v. INS, 899 F.2d 304, 313 (4 ${ }^{\text {th }}$ Cir. 1990) 

Zolfagharkhani v. Canada (Minister of Employment and Immigration) (C.A.) [1993] 3 F.C. 540, also available at $<$ http://www.canlii.org>.

$30 \quad$ Id. at p. $1-2$.

$31 \quad$ Id. at p. 8.

32 See, for example, Rostamzadeh-Jahan v. Canada (Minister of Employment and Immigration) [1993] 38 A.C.W.S. (3d) 571, also available at 1993 A.C.W.S.J. LEXIS 44101 (setting aside decision of Immigration and Refugee Board denying relief where Iranian testified he left the military before fulfilling his service because the Koran and Mohammed directs one not to kill one's Muslim brothers); Ciric v. Canada (Minister of Employment and Immigration) [1993] 71 F.T.R. 300 (setting aside decision of Board where Serbs did not want to serve in ongoing military action in Yugoslavia in the early 1990s).

33 Hinzman v. Canada (Minister of Citizenship and Immigration) (F.C.), 2006 F.C. 420 (CanLII), [2007] 1 F.C.R. 561, available at <http://www.canlii.org $>$.

34 Hughey v. Canada (Minister of Citizenship and Immigration), 2006 F.C. 421, available at <http://www.canlii. org $>$.

35 Hinzman, 2006 F.C. 420 para. 188.

36 Id. at para. 189.

37 Al Maisri v. Canada (Minister of Employment and Immigration), [1995] F.C.J. 642 (C.A.) (QL).

38 Hughey, 2006 F.C. 421, para. 224.

39 Id. at para. 225.

40 Amnesty International, AMR 51/075/2005, "USA: Jeremy Hinzman - Conscientious Objector seeking refuge in Canada," 13 May 2005.

41 [2003] UKHL 15, [2003] 1 W.L.R. 856 (appeal taken from Eng.) (U.K).

42 [2004] EWCA (Civ) 69, [2004] 1 W.L.R. 1825.

43 Id, at para 26, quoting B v. Secretary of State for the Home Department, [2003] UKIAT 20, para. 43.

44 Id, at para 26, quoting B v. Secretary of State for the Home Department, [2003] UKIAT 20, para. 46.

45 The RSAA does recognize that a viable claim may be based on Handbook paragraphs 169 (disproportionate punishment) or 171 (military action in contravention of human rights norms).

46 Refugee Appeal No. 2155/94 (1997) cited in Refugee Appeal No. $71219 / 99$ (1999) at p. 8, available at <http:// www.refugee.org.nz>.

47 Refugee Appeal No. $70625 / 97$ (1998) cited in Refugee Appeal No. 71219/99 (1999) at p.10, available at <http://www.refugee.org.nz>.

48 Refugee Appeal No. $71219 / 99$ (1999); Refugee Appeal No. 71055/98 (1998) cited in Refugee Appeal No. $71219 / 99$ (1999) at p.10, available at <http://www.refugee.org.nz>.

49 Refugee Appeal No. 75378/05 at para 112 (2005).

50 Id, at para. 43 .

51 Id, at para. 88 .

52 Id, at para. 142.

53 Cecilia M. Balliet, "Assessing Jus Ad Bellum and Jus in Bello Within the Refugee Status Determination Process: Contemplations on Conscientious Objectors Seeking Asylum,” 20 Georgetown Imm. L. J. 337, 367 (2006)

54 Id. at 367.

55 Qualification Directive, supra, n. 22.

56 Handbook, supra, n. 17.

57 UNHCR Annotated Comments on the EC Council Directive 2004/83/EC of 29 April 2004 on Minimum Standards for the Qualification and Status of Third Country Nationals or Stateless Persons as Refugees or as Persons who otherwise need International Protection and the Content of the Protection granted, (OJ L 304/12 of 30.9.2004) at 21 (2005), available at http://www.unhcr.org/protect/PROTECTION/43661 eee2.pdf.

58 ECRE Information Note on the Council Directive 2004/83/EC of 29 April 2004 on minimum standards for the qualification and status of third country nationals or stateless persons as refugees or as persons who otherwise need international protection and the content of the protection granted, IN1/10/2004/ext/CN, available at http://www.ecre.org/files/qualpro.pdf. 